\title{
Mapping potential foodsheds using regionalized consumer expenditure data for Southeastern Minnesota
}

\author{
Jake C. Galzki a * and David J. Mulla b \\ University of Minnesota \\ Erin Meier ${ }^{c}$ \\ University of Minnesota Extension
}

Submitted January 23, 2017 / Revised March 16, May 30, and June 1, 2017 / Accepted June 1, 2017 /

Published online August 28, 2017

Citation: Galzki, J. C., Mulla, D. J., \& Meier, E. (2017). Mapping potential foodsheds using regionalized

consumer expenditure data for Southeastern Minnesota. Journal of Agriculture, Food Systems, and Community

Development, 7(3), 181-196. http://dx.doi.org/10.5304/jafscd.2017.073.013

Copyright (C 2017 by New Leaf Associates, Inc.

\begin{abstract}
The theoretical concept of a foodshed is nearly a century old, while the tools used to model themcomputer software coupled with spatial and statistical datasets - are ever-evolving. In a previous study (Galzki, Mulla, \& Peters, 2014), foodshed maps have been created in Southeastern Minnesota that display the potential for local food system capacity in the region. Several assumptions were made based on data and software limitations that

a* Corresponding author: Jake Galzki, Research Fellow, Department of Soil, Water, and Climate, University of Minnesota; 1991 Upper Buford Circle; St. Paul, Minnesota 55108 USA; +1-612-720-4887; galzk001@,umn.edu

b David Mulla, Professor, Department of Soil, Water, and Climate, University of Minnesota, St. Paul, Minnesota; mulla003@umn.edu

${ }^{\mathrm{c}}$ Erin Meier, Program Director for the University of Minnesota Extension's Southeastern Regional Partnerships, Rochester, Minnesota; tegtm003@umn.edu
\end{abstract}

make the former results quite theoretical; this study attempts to move those results closer to reality by updating, where relevant. We utilized data produced by a model developed at the University of Minnesota to more effectively estimate regional food expenditures to create a representative diet in the region. We used current land-use data along with site-specific crop yields to analyze the potential food capacity of the region. We used optimization software to allocate food supplies to 53 cities in an attempt to feed all residents in the region and minimize food transportation distances. Improvements in software capacities allowed us to incorporate larger datasets, resulting in more detailed maps and statistics that better represent the potential of local foods in the region. The optimization model indicated the region is capable of sustaining its population entirely on locally derived foods. Each resident can be fed on approximately onethird of a hectare ( 0.85 acre) of land in the region. The average distance a unit of food travels from 
farm to grocery store was found to be $15.6 \mathrm{~km}(9.7$ miles). Results also show that $90 \%$ of the cultivated land remains in surplus after meeting the food demands of the region, minimizing the impacts on the local agroeconomic system. The surplus of pasture land is smaller, but over half the pasture land in the region is in surplus after food needs are met. We explore an alternative land-use scenario that removes environmentally sensitive cropland from cultivation to illustrate the impact conservation efforts may have on a potential local food system. The updated results of this study bolster the evocative effect of mapping foodsheds and provide a more realistic illustration of how the region could sustain itself on locally derived foods.

\section{Keywords}

Geographic Information Systems (GIS); Foodshed; Local Food System Capacity; Food System Mapping; Minnesota

\section{Introduction}

The term foodshed was originally introduced as analogous to watersheds. Instead of geographical landforms guiding the flow of water to an outlet, as in a watershed, foodsheds describe the economic forces that guide the flow of where food is produced and how it is transported to an outlet such as a city where it is consumed (Hedden, 1929). This concept introduced nearly a century ago was revisited to help illustrate how food systems work and to suggest that food sources must be protected (Getz, 1991). Foodsheds have been recently used to discuss a more locally reliant food system addressing issues such as food security and sustainability concerns as well as social and environmental impacts of food systems (Hendrickson, Kloppenburg, \& Stevenson 1996; Bills, Peters, \& Wilkins, 2009). The importance of a local food system is reflected in the benefits associated with it; these include local economic impacts, health and nutritional benefits, increased food security and sustainability, potential energy usage reductions, increased use of ecologically sound production and distribution methods, and the enhancement of social equity and democracy for a community (Feenstra, 1997; Martinez et al., 2010).

While foodsheds started as a conceptual idea, recent attempts to map them are producing visuals that illustrate local food system potential. A number of foodshed maps have been created for areas across North America as well as areas overseas (Peters, Bills, Wilkins, \& Fick, 2009; Hu, Wang, Arendt, \& Boeckenstedt, Boeckenstedt, \& Hu, 2011; Kremer \& DeLiberty, 2011; Musavi \& Holden, 2013). These often represent theoretical footprints that display what a local food system could look like on the landscape. An optimization model developed for New York State (Peters et al., 2007) considered an ideal diet, census population data, agricultural land-use data, and site-specific crop yield data to display the geographical extent of food demands in New York. This model was adapted to a region in Southeastern Minnesota by Galzki et al. (2014) and further updated here.

This study is one of a set of research projects funded by the University of Minnesota Southeast Regional Sustainable Development Partnership as part of its Southeast Foodshed Planning Initiative. The region has a decades-long local foods history that has cultivated a system continually growing and evolving today. This is evidenced by the number of producers, community supported agriculture farms, farmers markets, cooperative grocery stores, value-added local products on the shelves of natural food and mainstream groceries alike, as well as current developments around institutional markets, aggregation and distribution centers, and financing tools. Furthermore, fertile soils found in Southern Minnesota yield a high agricultural productivity in the region. When estimating each state's ability to supply itself with local foods, Timmons, Wang, and Lass (2008) found that Minnesota has the highest potential in the country; the study estimated the state can supply $90 \%$ of its food needs with locally grown food. Due to the amount of current local food framework and support mechanisms coupled with the high potential for agricultural food production, this region is a prime candidate for analysis of local food capacity.

\section{Study Area}

A 15-county region was defined in Southeastern Minnesota that acts as a boundary for both population data and agricultural production potential data within the foodshed model. Individual 
foodsheds are centered on population centers. It is assumed all food is delivered to this center directly from where it is produced, and the population will acquire food products from it. A population center was generated for every grocery outlet in the region, which resulted in 53 cities being used in attempt to represent the current system of food distribution (Figure 1). A Thiessen polygon analysis of these cities was used to aggregate census block data. In other words, residents of rural areas surrounding the 53 cities were assigned to their nearest population center, as it was assumed this is where they would acquire grocery products. The total population in the region is just over 620,000 people, which is largely dispersed in small towns and rural areas. Over 40 of the population centers have 10,000 or fewer residents. Rochester, the largest population center in the region, has 115,000 residents based on the Thiessen polygon analysis.

\section{Materials and Methods}

To determine potential food supply in the region, production zones were created which act as food supply points within the optimization model. Former studies utilizing this model employed $5 \mathrm{~km}$ (3.1 mi) by $5 \mathrm{~km}(3.1 \mathrm{mi})$ production zones (Galzki et al., 2014; Peters et al., 2009). Frontline's premium solver platform with an LP/QP (linear programming/quadratic programming) extended engine was utilized for this optimization (Frontline Systems, Inc., 2005). This extension, designed for large scale optimizations, implies higher computing power and increased the amount of data that can be accommodated by the model. Production zone size was decreased to $2 \mathrm{~km}(1.2 \mathrm{mi})$ by $2 \mathrm{~km}(1.2$ $\mathrm{mi})$ to increase detail in resulting maps and statistics. The amount of perennial and cultivated land was calculated for each zone. Within the model, annually cultivated lands create a supply of fruits,

\section{Figure 1. Extent of the Study Area in Southeastern Minnesota and the 53 Cities Used as Distribution} Points with Aggregated Population

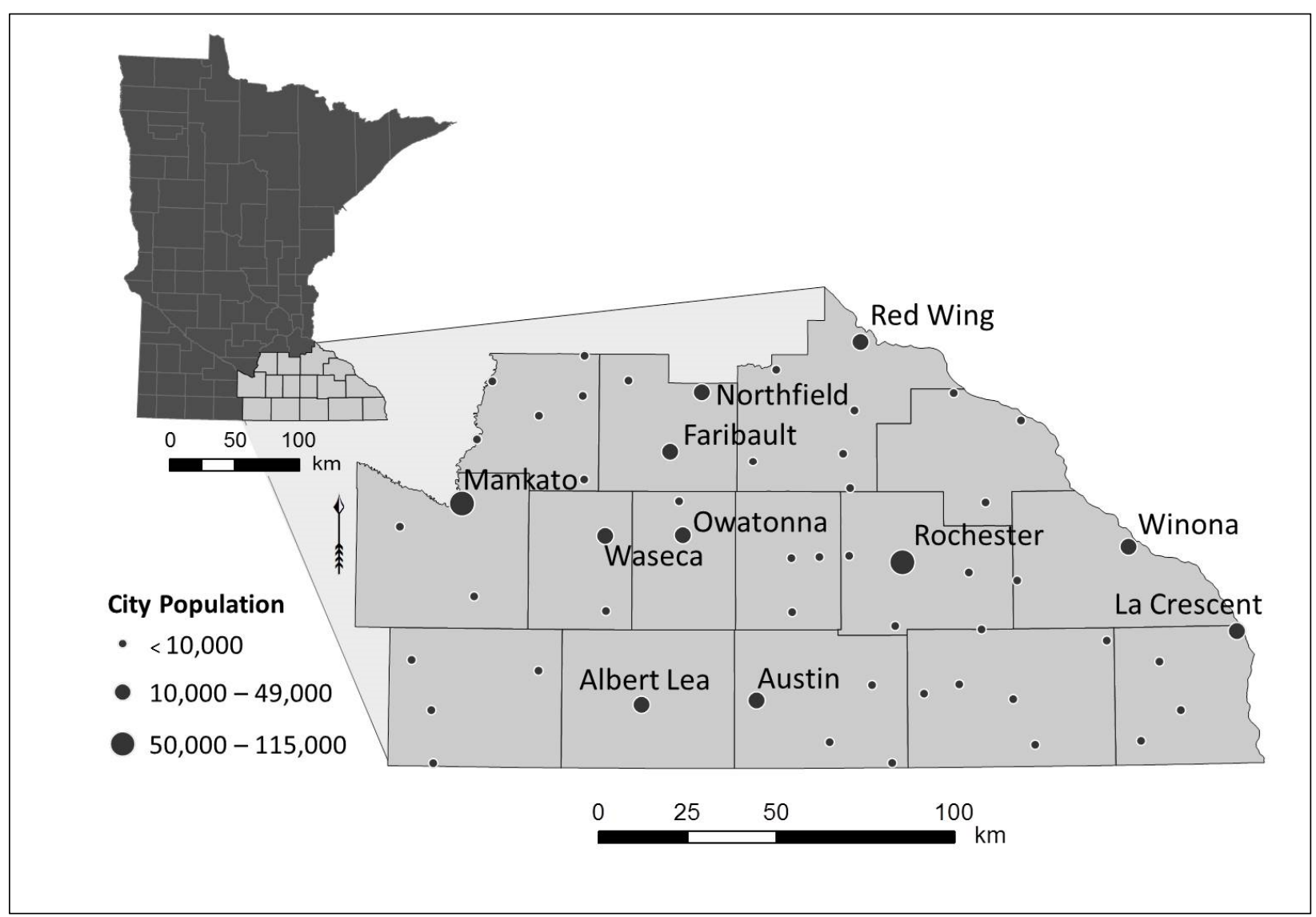


vegetables, and grains in the region and also include considerations for livestock feed. Since cultivation in Minnesota is restricted by its growing season, anticipated use of preserved and processed foods, such as canned vegetables in the winter, were also considered. Perennial lands, which represent pastured areas, are used to supply meat, milk, and eggs in the region.

Food demand in former studies has been based on a theoretical ideal diet based on food guide pyramid recommendations (Peters et al., 2009; Galzki et al., 2014). This 2300 kcal day- diet consisted of $170 \mathrm{~g}$ ( $6 \mathrm{oz}$.) of meat per person per day, with $40 \%$ of total calories coming from fat. This ideal basket of food originally created with New York climate considerations was termed a human nutritional equivalent and was adapted to Minnesota growing conditions covered in detail in previous work (Peters et al., 2007; Galzki et al., 2014). The diet accounted for seasonal food availability, as well as storage and processing losses with preservation methods.

To create a diet that more closely represents what residents in the area are consuming, recent economic survey data were analyzed. The most recent consumer expenditure survey at the time of analysis (U.S. Bureau of Labor Statistics, 2013) was utilized; this survey details categorical food expenditures and how they vary based on 10 demographic categories. In a process outlined by Wang (2011) and refined by Dietrich (2013) as part of the University of Minnesota's Southeast Foodshed Planning Initiative, these data were coupled with American Community Survey county-level demographic statistics to determine region specific food expenditures (U.S. Census Bureau, 2013). The consumer expenditure survey has two data categories that weren't considered because their constituents are too ambiguous to fit into the foodshed model. Food away from home largely represents restaurant expenses, and the miscellaneous foods category includes things such as frozen meals, spices, and condiments. By excluding these categories, the representative diet created considered only at home common food expenditures (Table 1).

The categories found in the consumer expenditure survey were aggregated into 7 groups for easy comparison to the ideal diet used previously by the model: grains, meat and eggs, fruit, vegetables, dairy, oils, and sweets. Since the ideal diet was modeled in portion size and not expenditures, prices for all constituents of the ideal diet were determined using historic 2008 retail food prices from the Bureau of Labor Statistics (n.d.) or fruit and vegetable prices from the Economic Research Service (n.d.). All prices were determined in 2008 US dollars for consistency. Once all commodity prices had been catalogued, the ideal diet was compared to regional consumer expenditures, and all portion sizes in the ideal diet were scaled to match current Southeastern Minnesota expenditures.

Recent estimates of average daily per capita calorie
Table 1. Categories and Brief Descriptions of the Consumer Expenditure Survey Used

\begin{tabular}{ll}
\hline Category & Brief Description \\
\hline Cereal & Flour, cereal, rice, pasta, etc. \\
\hline Bakery products & Bread, cakes, rolls, cookies, etc. \\
\hline Beef & All cuts of beef excluding canned \\
\hline Pork & All cuts of pork excluding canned ham \\
\hline Other meat & Hot dogs, lunchmeat, lamb, etc. \\
\hline Poultry & Chicken, turkey, other poultry \\
\hline Seafood & Canned, fresh, and frozen seafood \\
\hline Eggs & Eggs \\
\hline Milk products & Fresh milk and cream \\
\hline Other dairy & Butter, cheese, ice cream, yogurt, etc. \\
\hline Fresh fruit & Apples, bananas, citrus, etc. \\
\hline Processed fruit & Frozen fruit, juices, dried, canned \\
\hline Fresh vegetables & Potatoes, lettuce, carrots, etc. \\
\hline Processed vegetables & Frozen and canned vegetables, dried beans, etc. \\
\hline Sweets & Sugar, candy, jam, etc. \\
\hline Oils & Margarine, oils, salad dressings, etc. \\
\hline
\end{tabular}


intake for the United States are just under 2,600 kcal (USDA Economic Research Service, 2014), so the representative diet was scaled to reflect these data (Appendices 1 and 2).

Based on consumer expenditure analysis, distinct variance was observed in the ideal diet used in previous studies and the representative diet created here. Most notably, expenditures on vegetables in the region were half of what the food guide pyramid recommends for the ideal diet. The region is also spending less on meat and eggs. The regional expenditures are much higher for dairy products than the ideal diet, and sweets, grains, and fruit expenditures are slightly more than what is seen in ideal diet expenditures (Figure 2).

The representative diet created for the region was then translated into agricultural land demand by analyzing crop yields for each of the constituents of the diet. The original model used New York state crop yields; the model was adapted to Minnesota specific crop yields using five-year USDA National Agriculture Statistics Service (USDA NASS) (2011) data for all counties in the region. Crop yield goals were used when NASS data were not available (Rosen and Eliason, 2005). Processing losses, as well as adjustments for inedible portions, were both accounted for.
Additionally, feed crops were considered when determining land demands. A serving of beef, for instance, includes both the pasture land needed for grazing cattle in addition to annually cultivated land used to grow livestock feed. Because of these considerations, meat and dairy products require both pasture and cultivated land within the model.

Food demand was determined for each of the 53 cities based on the representative diet and population data. Supply of both cultivated land and pasture land was calculated for each of the $2 \mathrm{~km}$ $(1.2 \mathrm{mi})$ by $2 \mathrm{~km}$ production zones created in the region. Straight-line distances from each production zone to each city were also calculated, which the model used to minimize the sum of delivery distances from farm to supply point. The structure of the optimization was described previously by Peters et al. (2009). Frontline's Risk Solver Platform was used to carryout optimization within Microsoft Excel (Frontline Systems, Inc., 2005). A single spreadsheet was used containing a variable matrix that allowed the optimization software to explore every possible allocation scenario of delivering food products, derived from both cultivated and pasture lands, from each of the 6000 production zones to each of the 53 cities used in the region. The variable matrix was constrained by

Figure 2. Comparison of the Proportion of At-Home Expenditures for the Ideal Diet and the Representative Southeastern Minnesota Diet

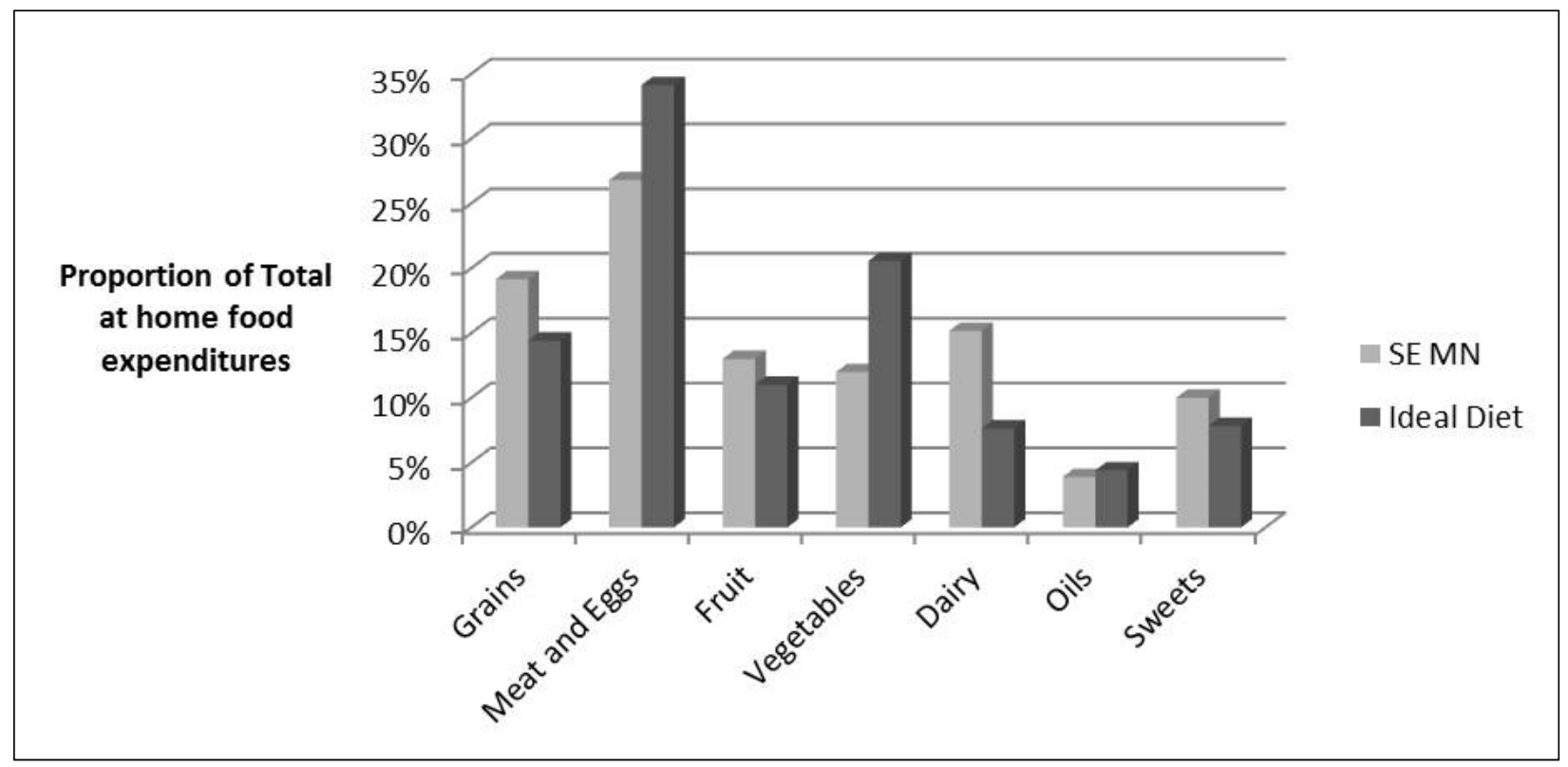


both the production potential within each zone and by the maximum production demanded by each population center. A distance matrix was used in the model that contained distances from each of the 6000 zones to each of the 53 cities. Finally, an equation summed the total distances of delivered food products for each allocation scenario, and the optimization determined the scenario with the lowest delivery distance in which either all food demand was met, or all agricultural supply was exhausted in the region.

\section{Alternative Land-use Scenario}

An alternative land-use scenario was explored to determine the potential impact of removing marginal cropland from cultivation in environmentally sensitive landscapes. Based on the constituents of the representative diet used, pasture land is both in higher demand and lower supply in the region. In this alternative scenario, a portion of annually cultivated lands was converted to pasture land where cropland was both marginal for productivity and environmentally vulnerable based on the indices described below. Annual cultivation in vulnerable areas can lead to environmental concerns such as soil degradation and surface water contamination. By removing a portion of land from cultivation, these issues can be addressed; also increasing the supply of pasture land would result in a decrease in foodshed size, implying reduced delivery distances.

Two indices were employed to determine lands suitable for removal from cultivation. The crop productivity index (CPI) was developed by the Natural Resources Conservation Service in Minnesota and represents a rating of potential yield of one soil against another. Ratings range from 0 , or lowest productivity, to 100 , or maximum productivity (Minnesota IT Services, n.d.). Due to a marginal production potential, cultivated land was selected based on $30 \mathrm{~m}$ grid cells with CPI ratings of 50 or less to be considered for conversion to pasture. A second index, the environmental benefits index (EBI), ranks lands based on their potential ecological benefit. The EBI values land that would benefit

${ }^{1}$ The Universal Soil Loss Equation is a widely accepted empirical formula developed by the USDA that estimates soil when removed from cultivation based on three different ecological concerns. The first represents a soil degradation risk based on the Universal Soil Loss Equation. ${ }^{1}$ The index also evaluates lands that have potential for providing quality habitat based on several habitat considerations. Finally, a high value is given to lands associated with a surface water quality risk based on both proximity to surface waters and overland flow paths. Each component contributes 100 points to the EBI with values ranging from 0 to 300 ; higher values indicate areas that would more strongly benefit from removal of annual cultivation (Minnesota Board of Water \& Soil Resources, n.d.). Lands where CPI is under 50 were intersected with areas that had EBI scores above 150 to represent both low-productivity and ecologically valuable land parcels. Characteristics of such lands suitable for conversion include cultivated areas with steeper slopes, shallow topsoil, close proximity to surface waters, or areas important for local biodiviersity.

\section{Results}

Even though daily caloric intake in the representative regional diet increases by nearly $300 \mathrm{kcal}$, the diet is made up of more products with higher food yields per acre, such as grains, and is lacking in meats and vegetables, which have lower food yields per acre. Due to the breakdown of the representative regional diet, it requires a smaller agricultural footprint than one following food guide pyramid recommendations with fewer calories. Based on this regional representative diet and Minnesota specific crop yields (Appendices 1 and 2), each person in the region requires $0.16 \mathrm{ha}(0.39 \mathrm{ac})$ of cultivated land and $0.18 \mathrm{ha}(0.46 \mathrm{ac})$ of pasture land to supply their nutritional demands for the year. The ideal diet used in a previous study within the region required the same amount of cultivated land, but an additional 0.05 ha $(0.12 \mathrm{ac})$ of pasture land was needed, making the agricultural footprint of the ideal diet larger despite how it provides fewer calories.

Using the updated regional diet, total agricultural land demand per person in Southeastern

erosion by rainfall impact and surface runoff (USDA ARS, n.d.). 
Minnesota is just under 0.35 ha $\mathrm{yr}(0.85 \mathrm{ac} \mathrm{yr})$. With 620,000 residents in the region, this translates into a total agricultural land demand of approximately 214,000 ha (530,000 ac). According to the Multi-Resolution Land Characteristics Consortium's (2011) National Land Cover Dataset, the 15county study area in Southeastern Minnesota contains nearly $1,700,00$ ha (over 4,000,000 acres) of agricultural land cover including both perennial pasture land and annually cultivated land, which is more than enough to sustain the population on local foods. However, within the region, $85 \%$ of all agricultural land is devoted to annual cultivation. Most of the western portion of the region contains flatter slopes and productive soils, where cultivation is focused. The eastern edge of the region is dominated by high-relief bluff lands draining to the Mississippi River and is where more of the pasture land exists. The proportion of cultivated and pasture lands, as well as their locations within the region, largely influence foodshed size and food delivery distances.

Considering food demands of the representative regional diet, regional population data, and the availability of cultivated and pasture land, the model concluded that it is feasible for Southeastern Minnesota to feed itself entirely on locally derived foods. The extent of each foodshed is again largely determined by the proximity of a city to cultivated and pasture land. The model outputs are mapped and illustrate both cultivated foodsheds and pasture foodsheds (Figures 3 and 4).

Of the $1,426,000$ ha $(3,500,000 \mathrm{ac})$ of annually cultivated land in the region, less than $10 \%$ is needed to provide the entirety of cultivated food demands of the population. Cultivated land is both in higher supply in the region and in lower demand based on the constituents of the representative diet, which is reflected in the small footprint defined by cultivated foodsheds and small food delivery distances relative to pasture land considerations. The average distance a unit of cultivated food travels within the modeled scenario is 10.8 $\mathrm{km}(6.7 \mathrm{mi})$.

As for pasture lands, 250,000 ha $(620,000 \mathrm{ac})$ exist in Southeast Minnesota. Of these available pasture lands, just under half are needed to provide for the local pasture food demand. Smaller supply of pasture lands coupled with a higher dietary demand translate into larger foodsheds and increased food travel distances. A unit of food derived from pasture land travels an average of $30 \mathrm{~km}$ (18.6 mi) to get from farm to distribution center. When cultivated and pasture food distances are combined based on their proportion of the total regional diet, the average distance each unit of food travels within the region is $15.6 \mathrm{~km}(9.7 \mathrm{mi})$.

The amount of agricultural land needed to meet food demands is only part of the actual areal coverage of the foodshed. Agricultural lands are intermixed with forest lands, urban areas, surface water, wetlands, and other land forms. Delivery paths are also included in the foodshed footprint, so if a parcel of agricultural land is not adjacent to the city it's delivered to, the cells along the delivery route are included. Thus, actual size of the foodshed footprint differs from agricultural land demanded in resulting statistics (Table 2).

\section{Alternative Land-use Scenario}

In this hypothetical scenario, cultivated lands that were defined as low productivity and ecologically valuable were removed from annual cropping practices to increase pasture land availability. Again, the overall goal is to explore the impact of one potential scenario of utilizing the large surplus of cultivated land in the region to benefit soil and water resources. Approximately 26,000 ha (63,000

Table 2. Agricultural Land Demand, Foodshed Footprint Size, and Food Delivery Distances for the Current and Alternative Land-use Scenarios

\begin{tabular}{|c|c|c|c|c|c|c|}
\hline & \multicolumn{3}{|c|}{ Current Land Use } & \multicolumn{3}{|c|}{ Alternative Scenario } \\
\hline & Cultivated & Pasture & Total & Cultivated & Pasture & Total \\
\hline Agricultural Land Demand (ha) & 98,600 & 114,700 & 213,300 & 98,600 & 114,700 & 213,300 \\
\hline Foodshed Footprint (ha) & 328,000 & $1,505,200$ & $1,546,000$ & 342,800 & $1,569,600$ & $1,618,800$ \\
\hline Food Delivery Distances (km) & 10.8 & 29.9 & 15.6 & 11.1 & 23.7 & 14.2 \\
\hline
\end{tabular}


Figure 3. Cultivated Foodsheds in Southeastern Minnesota

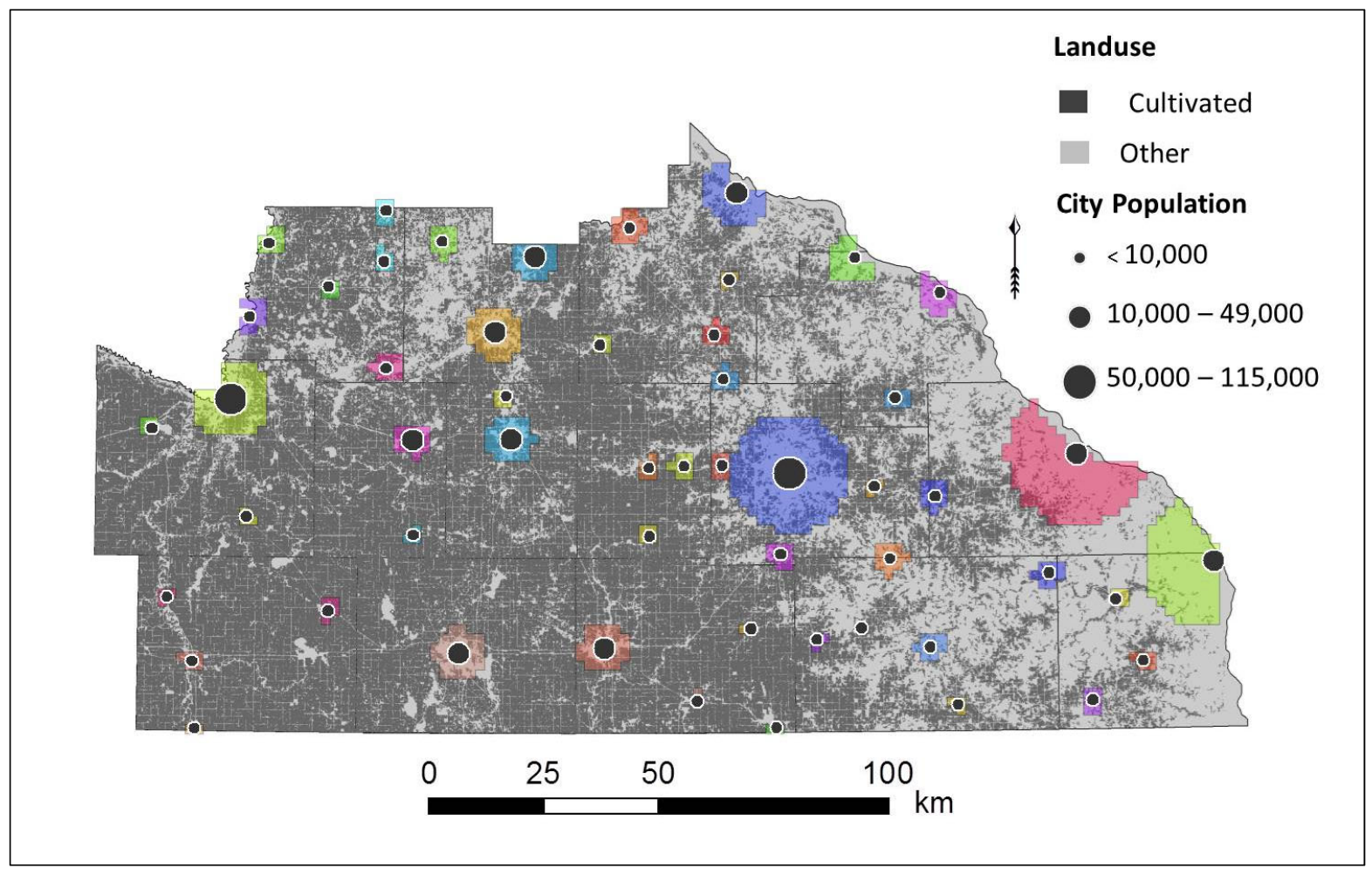

Figure 4. Pasture Foodsheds in Southeastern Minnesota

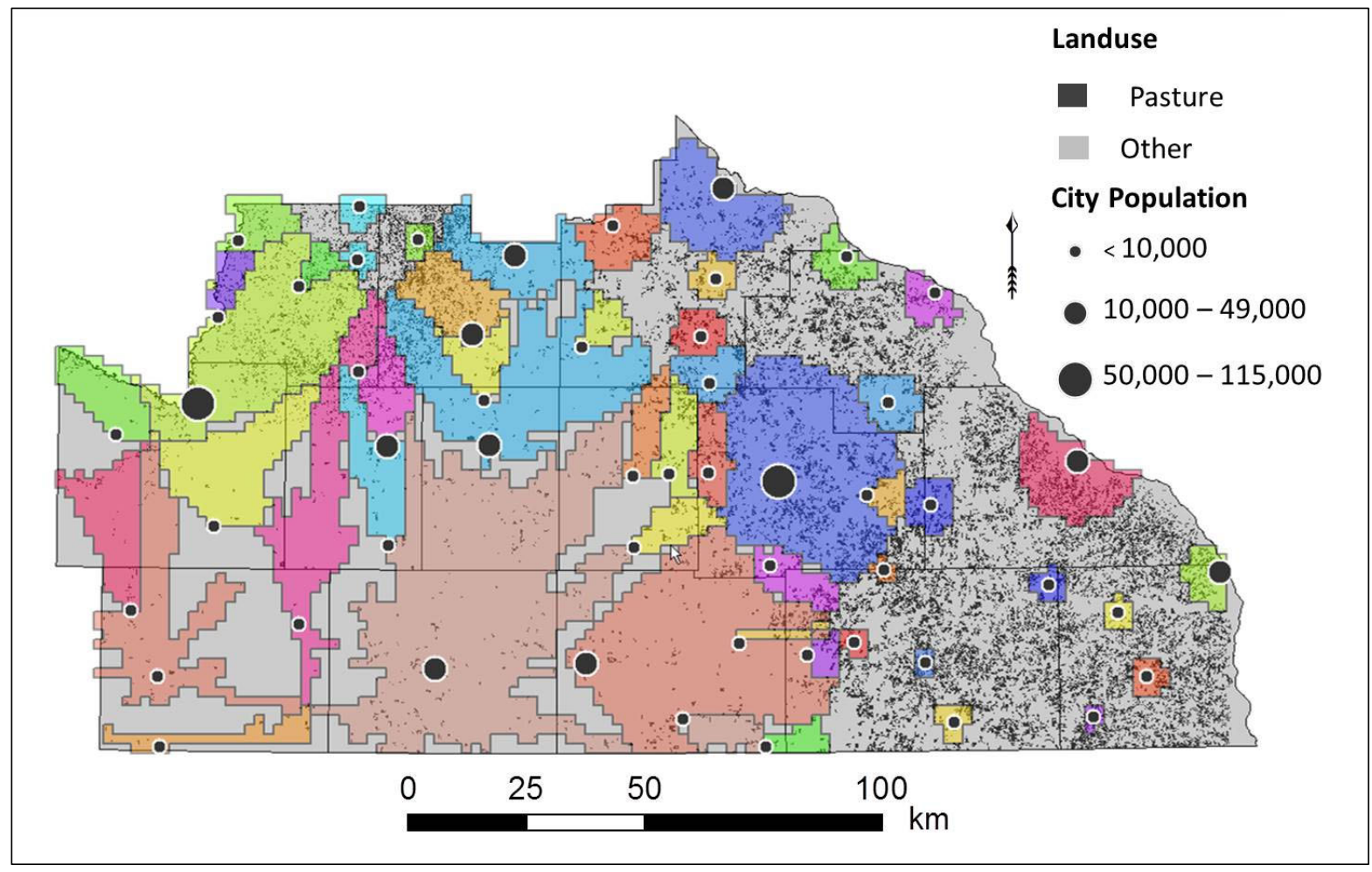


ac) were removed from cultivation and added to the potential supply of pasture land, which represents less than $2 \%$ of the available cultivated land in the region. This small-scale conversion would not only reduce potential pressure on soil and water resources in vulnerable areas, it also decreases the average total food delivery distance from $15.6 \mathrm{~km}(9.7 \mathrm{mi})$ to $14.2 \mathrm{~km}(8.8 \mathrm{mi})$. Since the model optimizes delivery distances and not foodshed footprint size, the footprint actually increases. This data artifact is a reflection of smaller more dissected parcels of pasture land that are closer in proximity to cities. Although they reduce delivery distances and satisfy the optimization, they require an increased number of delivery paths and thus a slight increase in footprint size (see Table 2).

\section{Discussion}

Soil and water conservation is simply one example of how an agricultural land surplus can be explored to further increase the benefits of utilizing local foods. From an economic standpoint, $90 \%$ of the regional cultivated land could be dedicated to commodity crops. When regional NASS land rental rates are used to value this land surplus, it could provide over $\$ 800$ million to the local economy. If agricultural land in Southeastern Minnesota is dedicated solely to provide local foods to Minnesotans, the 15-county area could supply all of the cultivated food demands and over $70 \%$ of the pasture food demands to the entire state's population of over 5 million people. When figuring the other $30 \%$ of pasture food needs could easily be met by Minnesota lands outside this region, one can conclude that Minnesota can theoretically be fed entirely on Minnesota grown foods based on the assumptions made in this study.

Although assumptions are made throughout this modeling process that create theoretical results, recent updates to the methodology and data inputs make these results much closer to reality than past iterations. The results found here illustrate local food potential in the region and have been disseminated to local stakeholders, stimulating interest in local foods and advancing the regional/local foods conversation. Demand for local foods in the region continues to grow, as do the number of farms that produce them (Low \&
Vogel, 2011; Martinez et al., 2010; National Farm to School Network, 2017; National Restaurant Association, 2014). Most of the growth to date has been associated with direct-to-consumer marketing. With consumer interest expanding beyond direct domestic purchases, the complex challenges of developing robust, fully-functioning local food systems have become more apparent. In addition, promotion of local food systems and associated sustainable production practices are now being embraced for their multiple social and natural resource benefits by professional societies such as the American Planning Association and the Academy of Nutrition and Dietetics (American Planning Association, 2007; Tagtow et al., 2014). For the first time, the environmental impacts of food production and the idea of sustainable diets for long-term food security have been included in the recommendations for revised federal dietary guidelines (Dietary Guidelines Advisory Committee, 2015). In Minnesota, public health and other partners are now also attempting to increase access to local foods as a health-improvement and equity strategy (Minnesota Department of Health, n.d.; Minnesota Food Charter, n.d.). This has also increased institutional demand for local foods in school and hospital cafeterias. Such demand significantly outweighs available supply, and public institutions purchasing large quantities of food cannot match the premium prices producers have been receiving via direct-to-consumer or tight intermediary markets such as restaurants. These developments are amplifying the ongoing challenges of aggregating supply from numerous farmers to meet high demand, adequate transportation, timely distribution, and satisfactory farmer income and livelihood. The results from this study provide additional information and encouragement to decision-makers in business and government to promote supportive policies and enterprise development investments in their local food systems.

Foodsheds in this study were created with widely available data. The original model developed for New York was updated with Minnesota specific crop yields, but it could be replicated for nearly any part of the country based on local crop or soil productivity data. Other data including population and land-use are available nationwide. 
With relative ease, this model could create foodsheds in nearly any part of the United States, or worldwide if appropriate data exists. Therefore local food potentials could be explored in nearly any geographical area and may lead to similarly informative results.

\section{Conclusions}

Based on the methods explained in this study, the 15-county region in Southeastern Minnesota has the theoretical capacity to feed itself entirely on locally derived foods. The model found that New York State could only feed one-third of its population on local foods. Although the extremely large population of New York City is an outlier affecting these results, it is encouraging to note the results of the model in the Midwest without the influence of a very large metropolitan area. The average distance a unit of food would travel in Southeastern Minnesota is $15.6 \mathrm{~km}(9.7 \mathrm{mi})$ compared to $49 \mathrm{~km}$ (30 mi) in New York State. Alternative land management techniques can be explored that not only reduce this travel distance to $14.2 \mathrm{~km}(8.8 \mathrm{mi})$, but could also reduce pressure on soil and water quality degradation.

Achieving a functional, viable local food system that is an integrated, significant component of a locale's overall food system has many hurdles, as noted above. Given the assumptions made in this modeling effort, the Southeastern region, and the state of Minnesota as a whole, have the capacity to meet the food requirements of local populations on locally produced foods. Illustrating this potential with foodsheds will hopefully evoke thought, inspire visions, and cultivate change in the region's food system. Foodshed maps could be generated for any region in the world with the potential for similarly illustrative results. Although these illustrations lack an economic analysis for the feasibility of local foods, they can and have been used to advance the conversation of local foods in the region. They offer a planning tool to move toward a reality of agricultural land clustered around population centers to meet some percentage of food self-reliance and the creation of a sustainable food system for future generations.

\section{References}

American Planning Association. (2007). Policy guide on community and regional food planning. Retrieved in May 2015 from https://www.planning.org/policy/guides/adopted/food.htm

Dietary Guidelines Advisory Committee. (2015). Scientific report of the 2015 Dietary Guidelines Advisory Committee, Part D. Chapter 5: Food sustainability and safety. Retrieved from http://health.gov/dietaryguidelines/2015-scientific-report/10chapter-5/

Dietrich, S. (2013). Feeding Southeast Minnesota: A model to estimate food expenditures and quantities. Unpublished master's thesis, University of Minnesota Department of Applied Economics.

Feenstra, G. W. (1997). Local food systems and sustainable communities. American Journal of Alternative Agriculture, 12(1), 28-36. https://doi.org/10.1017/S0889189300007165

Frontline Systems, Inc. (2005). Premium Solver Platform for use with Microsoft Excel®. Retrieved from http://www.solver.com

Galzki, J. C., Mulla, D. J., \& Peters, C. J. (2014). Mapping the potential of local food capacity in Southeastern Minnesota. Renewable Agriculture and Food Systems, 30(4), 364-372. http://dx.doi.org/10.1017/S1742170514000039

Getz, A. (1991). Urban foodsheds. The Permaculture Activist, 24, 26-27.

Hedden,W. P. (1929). How great cities are fed. Boston: D.C. Heath.

Hu, G., Wang, L., Arendt, S., \& Boeckenstedt, R. (2011). An optimization approach to assessing the self-sustainability potential of food demand in the Midwestern United States. Journal of Agriculture, Food Systems, and Community Development, 2(1), 195-207. https://doi.org/10.5304/jafscd.2011.021.004

Kloppenburg, J., Hendrickson, J., \& Stevenson, G. W. (1996). Coming in to the foodshed. Agriculture and Human Values, 13(3), 33-42. https://doi.org/10.1007/BF01538225

Kremer, P., \& DeLiberty, T. L. (2011). Local food practices and growing potential: Mapping the case of Philadelphia. Applied Geography, 31(4), 1252-1261. https://doi.org/10.1016/j.apgeog.2011.01.007 
Low, S. A., \& Vogel, S. (2011). Direct and intermediated marketing of local foods in the United States (Economic Research Report No. 128). Washington, D.C.: USDA Economic Research Service. Retrieved from https://www.ers.usda.gov/webdocs/publications/44924/8276 err128 2 .pdf?v $=41056$

Martinez, S., Hand, M. S., Da Pra, M., Pollack, S., Ralston, K., Smith, T.,... Newman, C. (2010). Local food systems: Concepts, impacts, and issues (Economic Research Report No. 97). Washington, D.C.: USDA Economic Research Service. Retrieved from https://www.ers.usda.gov/webdocs/publications/46393/7054_err97_1_.pdf?v=42265

Minnesota Board of Water \& Soil Resources. (n.d.). Ecological Ranking Tool. Retrieved August 23, 2017, from http://www.bwsr.state.mn.us/ecological_ranking/

Minnesota Department of Health. (n.d.). The Statewide Health Improvement Program. Retrieved May 2015 from http://www.health.state.mn.us/ship/

Minnesota Food Charter. (n.d.). Minnesota Food Charter. Retrieved May 2015 from http://mnfoodcharter.com/

Minnesota IT Services. (n.d.). Crop productivity index ratings for Minnesota. Retrieved August 1, 2017, from http://www.mngeo.state.mn.us/chouse/soil cpi.html

Multi-Resolution Land Characteristics Consortium. (2011). National Land Cover Database 2011. Retrieved January 2014 from http://www.mrlc.gov/nlcd2011.php

Musavi, A., \& Holden, N. M. (2013). Ireland's foodshed as a practical model to promote sustainability. Biosystems Engineering Research Review, 18, 123-126. http://hdl.handle.net/10197/4385

National Farm to School Network. (2017). The benefits of farm to school [Fact sheet]. Retrieved from http://www.farmtoschool.org/Resources/BenefitsFactSheet.pdf

National Restaurant Association. (2014). 2015 Culinary Forecast. Retrieved from http://www.restaurant.org/Downloads/PDFs/News-Research/WhatsHot2015-Results.pdf

Peters, C. J., Bills, N. L., Lembo, A. J., Wilkins, J. L., \& Fick, G. W. (2009). Mapping potential foodsheds in New York State: A spatial model for evaluating the capacity to localize food production. Renewable Agriculture and Food Systems, 24(1), 72-84. https://doi.org/10.1017/s1742170508002457

Peters, C. J., Bills, N. L., Wilkins, J. L., \& Fick, G. W. (2009). Foodshed analysis and its relevance to sustainability. Renewable Agriculture and Food Systems, 24(1), 1-7. https://doi.org/10.1017/S1742170508002433

Peters, C. J., Wilkins, J. L., \& Fick, G. W. (2007). Testing a complete-diet model for estimating the land resource requirements of food consumption and agricultural carrying capacity: The New York state example. Renewable Agriculture and Food Systems, 22(2), 145-153. https://doi.org/10.1017/S1742170507001767

Rosen, C. J., \& Eliason, R. (2005). Nutrient management for commercial fruit and vegetable crops in Minnesota. St. Paul: University of Minnesota Extension Service. Retrieved from https://www.extension.umn.edu/garden/fruitvegetable/nutrient-management-for-commercial-fruit-and-vegetables-in-mn/

Tagtow, A., Robien, K., Bergquist, E., Bruening, M., Dierks, L., Hartman, B. E.,... Wilkins, J. (2014). Academy of Nutrition and Dietetics: Standards of Professional Performance for Registered Dietitian Nutritionists (Competent, Proficient, and Expert) in sustainable, resilient, and healthy food and water systems. Journal of the Academy of Nutrition and Dietetics, 114(3), 475-488. https://doi.org/10.1016/i.jand.2013.11.011

Timmons, D., Wang, Q., \& Lass, D. (2008). Local foods: Estimating capacity. Journal of Extension, 46(5), Article 5FEA7. https://www.joe.org/joe/2008october/a7.php

U.S. Bureau of Labor Statistics. (n.d.). Average retail food and energy prices, U.S. and Midwest region [Table]. Retrieved January 2014 from http://www.bls.gov/regions/mid-Atlantic/data/AverageRetailFoodAndEnergyPrices Usand Midwest Table.htm

U.S. Bureau of Labor Statistics. (2013). Consumer Expenditure Survey. Retrieved April 20, 2013, from www.bls.gov/cex/

U.S. Census Bureau. (2010). Centers of population by block group. Retrieved from https://www.census.gov/geo/reference/centersofpop.html

U.S. Census Bureau. (n.d.). American Community Survey: Data tables \& tools. Retrieved April 20, 2013, fromhttps://www.census.gov/acs/www/data/data-tables-and-tools/index.php

U.S. Department of Agriculture Agricultural Research Service [USDA ARS]. (n.d.). About the Universal Soil Loss Equation. Retrieved August 2017 from https://www.ars.usda.gov/midwest-area/west-lafayette-in/national-soil-erosionresearch/docs/usle-database/research/ 
USDA Economic Research Service [USDA ERS]. (n.d.). Fruit and vegetable prices. Retrieved January 2014 from http://www.ers.usda.gov/data-products/fruit-and-vegetable-prices.aspx\#.UkQz6j-D18F

USDA ERS. (2014). Food Availability (Per Capita) Data System: Loss-adjusted food availability: Calories. Retrieved January 2014 from https://www.ers.usda.gov/data-products/food-availability-per-capita-data-system/food-availability-percapita-data-system/\#Loss-Adjusted $\% 20$ Food $\% 20$ Availability

USDA National Agriculture Statistics Service. (2011). County crop yield data. Retrieved January 2014 from https://www.nass.usda.gov/Data and Statistics/

University of Minnesota Duluth, Natural Resources Research Institute. (n.d.). Environmental Benefits Index. Retrieved August 1, 2017, from http://beaver.nrri.umn.edu/EcolRank/ebi/

Wang, Y. (2011). Predicting aggregate food consumption for a specific geographic area: An application to southeast Minnesota (Master's thesis). University of Minnesota Department of Applied Economics. http://purl.umn.edu/161441 
Appendix A. Constituents of the Ideal Diet for Summer Months as Well as Average Yields for Southeastern Minnesota and Estimated Consumption for Each Processed Constituent

\begin{tabular}{|c|c|c|}
\hline & Average Yield & $\begin{array}{c}\text { Estimated Consumption } \\
\text { (g/person/day) }\end{array}$ \\
\hline \multicolumn{3}{|l|}{ GRAINS } \\
\hline Wheat & $43 \mathrm{bu} / \mathrm{ac}$ & 219.7 \\
\hline Rye & $30 \mathrm{bu} / \mathrm{ac}$ & 1.5 \\
\hline Corn & $145 \mathrm{bu} / \mathrm{ac}$ & 17.5 \\
\hline Oats & $73 \mathrm{bu} / \mathrm{ac}$ & 11.0 \\
\hline \multicolumn{3}{|l|}{ VEGETABLES } \\
\hline Carrots (fresh) & $400 \mathrm{cwt} / \mathrm{ac}$ & 16.7 \\
\hline Endive/escarole (fresh) & $180 \mathrm{cwt} / \mathrm{ac}$ & 0.3 \\
\hline Lettuce (fresh) & $300 \mathrm{cwt} / \mathrm{ac}$ & 22.1 \\
\hline Spinach (fresh) & $150 \mathrm{cwt} / \mathrm{ac}$ & 2.2 \\
\hline Squash, winter (fresh) & $300 \mathrm{cwt} / \mathrm{ac}$ & 3.9 \\
\hline Beets (canned) & $10 \mathrm{t} / \mathrm{ac}$ & 1.2 \\
\hline Bell peppers (fresh) & $200 \mathrm{cwt} / \mathrm{ac}$ & 2.4 \\
\hline Cabbage (fresh) & $400 \mathrm{cwt} / \mathrm{ac}$ & 2.3 \\
\hline Cauliflower (fresh) & $150 \mathrm{cwt} / \mathrm{ac}$ & 0.8 \\
\hline Cucumbers (fresh) & $250 \mathrm{cwt} / \mathrm{ac}$ & 3.3 \\
\hline Eggplant (fresh) & $250 \mathrm{cwt} / \mathrm{ac}$ & 0.5 \\
\hline Onions (fresh) & $500 \mathrm{cwt} / \mathrm{ac}$ & 11.7 \\
\hline Snap beans (fresh) & $3 \mathrm{t} / \mathrm{ac}$ & 4.3 \\
\hline Tomatoes (fresh) & $270 \mathrm{cwt} / \mathrm{ac}$ & 36.7 \\
\hline Green peas (frozen) & $1.5 \mathrm{t} / \mathrm{ac}$ & 3.3 \\
\hline Green peas (canned) & $1.5 \mathrm{t} / \mathrm{ac}$ & 3.5 \\
\hline Potatoes (fresh) & $167 \mathrm{cwt} / \mathrm{ac}$ & 41.2 \\
\hline Sweet corn (fresh) & $7 \mathrm{t} / \mathrm{ac}$ & 11.2 \\
\hline \multicolumn{3}{|l|}{ FRUIT } \\
\hline Blueberries (fresh) & $50 \mathrm{cwt} / \mathrm{ac}$ & 6.8 \\
\hline Strawberries (fresh) & $100 \mathrm{cwt} / \mathrm{ac}$ & 24.4 \\
\hline Apples (fresh) & $140 \mathrm{cwt} / \mathrm{ac}$ & 88.9 \\
\hline Cherries (fresh) & $45 \mathrm{cwt} / \mathrm{ac}$ & 3.1 \\
\hline Grapes (fresh) & $60 \mathrm{cwt} / \mathrm{ac}$ & 19.5 \\
\hline Plums (fresh) & $80 \mathrm{cwt} / \mathrm{ac}$ & 33.8 \\
\hline Pears (fresh) & $100 \mathrm{cwt} / \mathrm{ac}$ & 32.3 \\
\hline Apple juice & $8,840 \mathrm{lbs} / \mathrm{ac}$ & 106.8 \\
\hline Grape juice & $4,180 \mathrm{lbs} / \mathrm{ac}$ & 46.8 \\
\hline \multicolumn{3}{|l|}{ DAIRY } \\
\hline Milk - whole $(3.7 \%) *$ & $4,917 \mathrm{lbs} / \mathrm{ac}$ & 987.3 \\
\hline \multicolumn{3}{|l|}{ PULSES } \\
\hline Beans - black & $2,361 \mathrm{lbs} / \mathrm{ac}$ & 0.6 \\
\hline Beans - kidney & $2,361 \mathrm{lbs} / \mathrm{ac}$ & 0.6 \\
\hline Soybeans & $47 \mathrm{bu} / \mathrm{ac}$ & 0.7 \\
\hline
\end{tabular}




\begin{tabular}{lcc}
\hline & Average Yield & $\begin{array}{c}\text { Estimated Consumption } \\
\text { (g/person/day) }\end{array}$ \\
\hline NUTS AND SEEDS & $1,105 \mathrm{lbs} / \mathrm{ac}$ & 0.3 \\
\hline Sunflower seeds & $1,561 \mathrm{lbs} / \mathrm{ac}$ & 37.0 \\
\hline MEAT AND EGGS & $1,800 \mathrm{lbs} / \mathrm{ac}$ & 30.8 \\
\hline Beef* & $1,577 \mathrm{lbs} / \mathrm{ac}$ & 47.8 \\
\hline Pork* & $3,721 \mathrm{lbs} / \mathrm{ac}$ & 26.6 \\
\hline Chicken* & & 1.0 \\
\hline Eggs* & $1,527 \mathrm{lbs} / \mathrm{ac}$ & 16.5 \\
\hline OILS & $2,823 \mathrm{lbs} / \mathrm{ac}$ & 0.1 \\
\hline Canola oil & $1,517 \mathrm{lbs} / \mathrm{ac}$ & 70.3 \\
\hline Soybean oil & & \\
\hline Sunflower oil & $30,000 \mathrm{lbs} / \mathrm{ac}$ & \\
\hline SUGARS & & \\
\hline Beet sugar & & \\
\hline$*$ Yield values represent pounds & & \\
\hline
\end{tabular}

* Yield values represent pounds of processed edible product 
Appendix B. Constituents of the Ideal Diet for Winter Months as Well as Average Yields for Southeastern Minnesota and Estimated Consumption for Each Processed Constituent

\begin{tabular}{|c|c|c|}
\hline & Average Yield & $\begin{array}{l}\text { Estimated Consumption } \\
\text { (g/person/day) }\end{array}$ \\
\hline \multicolumn{3}{|l|}{ GRAINS } \\
\hline Wheat & $43 \mathrm{bu} / \mathrm{ac}$ & 214.0 \\
\hline Rye & $30 \mathrm{bu} / \mathrm{ac}$ & 1.5 \\
\hline Corn & $145 \mathrm{bu} / \mathrm{ac}$ & 17.1 \\
\hline Oats & $73 \mathrm{bu} / \mathrm{ac}$ & 10.7 \\
\hline \multicolumn{3}{|l|}{ VEGETABLES } \\
\hline Carrots (fresh) & $400 \mathrm{cwt} / \mathrm{ac}$ & 33.9 \\
\hline Squash, winter (fresh) & $300 \mathrm{cwt} / \mathrm{ac}$ & 7.9 \\
\hline Spinach (frozen) & $150 \mathrm{cwt} / \mathrm{ac}$ & 14.8 \\
\hline Beets (canned) & $10 \mathrm{t} / \mathrm{ac}$ & 1.4 \\
\hline Cabbage (fresh) & $400 \mathrm{cwt} / \mathrm{ac}$ & 2.6 \\
\hline Cauliflower (frozen) & $150 \mathrm{cwt} / \mathrm{ac}$ & 1.7 \\
\hline Onions (fresh) & $500 \mathrm{cwt} / \mathrm{ac}$ & 13.3 \\
\hline Snap beans (frozen) & $3 \mathrm{t} / \mathrm{ac}$ & 2.8 \\
\hline Snap beans (canned) & $3 \mathrm{t} / \mathrm{ac}$ & 2.8 \\
\hline Tomatoes (canned) & $270 \mathrm{cwt} / \mathrm{ac}$ & 59.1 \\
\hline Green peas (frozen) & $1.5 \mathrm{t} / \mathrm{ac}$ & 3.2 \\
\hline Green peas (canned) & $1.5 \mathrm{t} / \mathrm{ac}$ & 3.4 \\
\hline Potatoes (fresh) & $167 \mathrm{cwt} / \mathrm{ac}$ & 40.2 \\
\hline Sweet corn (frozen) & $7 \mathrm{t} / \mathrm{ac}$ & 6.2 \\
\hline Sweet corn (canned) & $7 \mathrm{t} / \mathrm{ac}$ & 6.2 \\
\hline \multicolumn{3}{|l|}{ FRUIT } \\
\hline Apple juice & $8,840 \mathrm{lbs} / \mathrm{ac}$ & 104.0 \\
\hline Grape juice & $4,180 \mathrm{lbs} / \mathrm{ac}$ & 45.6 \\
\hline Blueberries (frozen) & $50 \mathrm{cwt} / \mathrm{ac}$ & 4.2 \\
\hline Strawberries (frozen) & $100 \mathrm{cwt} / \mathrm{ac}$ & 20.3 \\
\hline Apples (fresh) & $140 \mathrm{cwt} / \mathrm{ac}$ & 99.9 \\
\hline Cherries (frozen) & $45 \mathrm{cwt} / \mathrm{ac}$ & 1.9 \\
\hline Plums (canned) & $80 \mathrm{cwt} / \mathrm{ac}$ & 25.6 \\
\hline Pears (fresh) & $100 \mathrm{cwt} / \mathrm{ac}$ & 36.4 \\
\hline \multicolumn{3}{|l|}{ DAIRY } \\
\hline Milk - whole $(3.7 \%)^{*}$ & $4,917 \mathrm{lbs} / \mathrm{ac}$ & 999.3 \\
\hline \multicolumn{3}{|l|}{ PULSES } \\
\hline Beans - black & $2,361 \mathrm{lbs} / \mathrm{ac}$ & 0.6 \\
\hline Beans - kidney & $2,361 \mathrm{lbs} / \mathrm{ac}$ & 0.6 \\
\hline Soybeans & $47 \mathrm{bu} / \mathrm{ac}$ & 0.8 \\
\hline \multicolumn{3}{|l|}{ NUTS AND SEEDS } \\
\hline Sunflower seeds & $1,105 \mathrm{lbs} / \mathrm{ac}$ & 0.3 \\
\hline \multicolumn{3}{|l|}{ MEAT AND EGGS } \\
\hline Beef* & $1,561 \mathrm{lbs} / \mathrm{ac}$ & 37.4 \\
\hline
\end{tabular}


Journal of Agriculture, Food Systems, and Community Development ISSN: 2152-0801 online http://www.foodsystemsjournal.org

\begin{tabular}{llc}
\hline & Average Yield & $\begin{array}{c}\text { Estimated Consumption } \\
\text { (g/person/day) }\end{array}$ \\
\hline Pork* & $1,800 \mathrm{lbs} / \mathrm{ac}$ & 31.2 \\
\hline Chicken* & $1,577 \mathrm{lbs} / \mathrm{ac}$ & 48.4 \\
\hline Eggs* & $3,721 \mathrm{lbs} / \mathrm{ac}$ & 26.9 \\
\hline OILS & & 1.0 \\
\hline Canola oil & $1,527 \mathrm{lbs} / \mathrm{ac}$ & 16.7 \\
\hline Soybean oil & $2,823 \mathrm{lbs} / \mathrm{ac}$ & 0.1 \\
\hline Sunflower oil & $1,517 \mathrm{lbs} / \mathrm{ac}$ & \\
\hline SUGARS & & 71.0 \\
\hline Beet sugar & $30,000 \mathrm{lbs} / \mathrm{ac}$ &
\end{tabular}

* Yield values represent pounds of processed edible product 